\title{
Performance of Paddy Varieties against Brown Leaf Spot Disease under Flooded Conditions in Mandya District, Karnataka, India
}

\author{
C. Channakeshava* and N.S. Pankaja \\ Department of Plant Pathology, College of Agriculture, V.C. Farm, Mandya, India \\ *Corresponding author
}

Ke y w o r d s
Paddy, Brown leaf spot,
$\begin{aligned} & \text { Disease severity, } \\ & \text { Screening and MTU } 1001\end{aligned}$
Article Info
Accepted:
04 November 2018
Available Online:
10 December 2018

\section{A B S T R A C T}

Rice is an important food crop in India. One of the major constraints of rice production is that it is prone to several diseases. Among them brown leaf spot disease has been reported to occur in all rice growing regions. A study was conducted to determine the performance of fifty paddy varieties against the disease at college of agriculture, V.C. Farm, Mandya, during kharif 2015. The per cent disease severity was recorded at 30,60 and 90 days after transplanting (DAT). It was observed that, the disease severity increased with increase in age of the crop from 30-90 DAT. However, there was no disease at 30 DAT in any of the genotypes. At 60 DAT the average disease severity ranged from 0.0 to $13.55 \%$, whereas at 90 DAT it ranged from 0.0 to $21.20 \%$. A moderately resistant reaction to the disease was noticed in 31 genotypes. Further, 11 genotypes viz., Rasi, JGL-1798, BR-2655, Raksha, KMP-201, BI-33, Sagbatta, Honnekattu, Klame, Kavekantak and Togarshi were identified as the resistant sources against the disease as they were free from the disease throughout the cropping period, which could be used by the breeders to improve the yield of the rice crops.

\section{Introduction}

Rice (Oryza sativa L.) fulfills the need of food product in the most of the developing countries of the world. It provides energy in the form of starch and about half of the world population depended upon the rice in per day meal. More than 3.5 billion people depended on rice for more than $20 \%$ of their daily calories (IRRI Rice facts, 2012).

According to (FAO, 2010) rice is cultivated in 114 countries and has got third rank in the world after maize and wheat. India produce $2240 \mathrm{~kg} / \mathrm{ha}$ rice annually. India rank second in terms of production in world being next to the China (FAO, 2010).

In India, rice grown on above one-fourth of the total crop area and provides food to about half of the country's population. Rice is playing a vital role in our national food security. It's growing in the different part of country due to their wide adaptability. Due to infection of several types of pathogens, resulting causes extensive damage to the crop. Fungi alone account for nearly 30 diseases of rice in the country (Rangaswami and Mahadevan, 1992). Among these, a few occur in epiphytotic form in many parts of India and 
one of the important disease is brown leaf spot of paddy caused by Bipolaris oryzae Shoemaker (Heliminthosporium oryzae Breda de Hann) which caused havoc loss in Bengal during 1942-43.

Brown leaf spot disease is the most serious disease of rice Arshad et al., (2008). It caused Bengal Famine in 1942, with yield loss of 50$90 \%$, which resulted in death of 2 million people due to starvation. The pathogen can infects both seedlings and mature plants with the coleoptile, leaves, leaf sheath, panicle branches, glumes, and spike lets (Webster and Gunnell, 1992). The disease is also known as poor rice farmer's disease because it occurs mostly in deficient and poor soils (Agarwal, 1989; Khan et al., 2001 and Zadoks, 2002). The disease has been noted to reduce yields from 6 to 90\% in Asia (Padmanabhan, 1973; Estrada, 1984).

The severity of brown spot disease can be managed through development of resistant lines (Mew et al., 1991; Bonman et al., 1991). Reaction of 31 rice genotypes was evaluated in field against brown leaf spot disease under low water application condition by Yaqoob et al., 2011. The disease was scored using 1-9 rating scale. The late maturing lines $\mathrm{HHZB}$, IR80416-B-32-3, IR84677-34-1-B and HHZ11-Y6-Y1-Y1 were found to be highly resistant against brown leaf spot by scoring 1 . Medium and early maturing lines showed susceptible reaction by scoring 5. Pannu et al., (2006) observed the reaction of paddy varieties PR-116, PR-114, PR-106, PR-103, PR-108, PR-113, PR-111 and PR-115 against brown leaf spot and reported PR-116, PR-114 and PR-106 to be more susceptible with per cent disease severity of $28.41,23.13$ and 19.57 respectively. Alam et al., (2016) screened 25 rice varieties against brown leaf spot caused by Helminthosporium oryzae during session Kharif2014 and 2015. The results were four varieties recorded viz. NDR-359, CR-1, CR-2 and N-18 in highly resistant. Seven varieties were recorded viz. PR-103, IR-36, Prasd, Narendra-2, IR-597, OC-1339 and Cross-116 in resistant.

Karnataka has made rapid progress in rice cultivation during the last few years. Mandya, Uttar Kannada, Mysuru, Raichur and Kodagu are the main producers. It is grown in all the three seasons viz., kharif, rabi and summer under rainfed and irrigated conditions. In view of the above facts the present study was conducted to investigate the severity of brown spot of paddy in mostly cultivated varieties in Mandya district and to know the most susceptible growth stage of rice due this diseases. To achieve these goals, different varieties were selected which are mostly cultivated in Kharif and Rabi season in Mandya district.

\section{Materials and Methods}

In the present investigation fifty paddy genotypes were collected at AICRP on rice at Zonal Agricultural Research Station (ZARS), V.C. Farm, Mandya, to screen against brown leaf spot disease. The collected seed samples were stored at room temperature in polythene bags. The seeds were sown in the nursery beds and normal agronomic practices were followed to ensure proper plant growth. Twenty six days old seedlings were transplanted in the main field under wet land condition, during kharif2015 at College of Agriculture, V.C. Farm, Mandya.

Infector row technique was followed to evaluate the genotypes wherein, each genotype was sown in two lines of $4.5 \mathrm{~m}$ length with a spacing of $30 \mathrm{~cm} \mathrm{x} 15 \mathrm{~cm}$ (Cardwell et al., 1997). MTU 1001 was used as a susceptible check. 2 lines of MTU 1001 were sown at every 10 rows interval. Regular package of practices were carried out until harvest of the crop. Observations were 
recorded at thirty days interval. Disease scoring was done by employing SES scale developed by IRRI in 1996 as mentioned in Table 1.

Percent disease index (PDI) will be calculated by using formula given by Wheeler (1969).

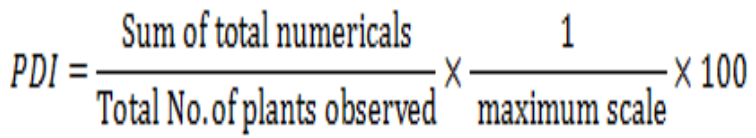

\section{Results and Discussion}

The results of the genotypes screened against the disease from the present study are presented in Table 2. The per cent disease severity of the disease was recorded at 30, 60 and 90 days after transplanting (DAT). Disease severity increased with increase in age of the crop from 30-90 DAT. However, there was no disease at 30 DAT in any of the genotypes. At 60 DAT the disease severity ranged from 0.0 to 13.55 per cent. Highest disease severity of 13.55 per cent was recorded on the variety Rajmudi followed by 13.40 per cent in MTU-1010. 13 varieties viz., Rasi, JGL-1798, BR-2655, Raksha, KMP-201, KMP-128, BI-33, Sag batta, Honnekatte, Klame, Akkalu, Kavekantak and Togarshi did not produce any kind of disease symptoms. However on the susceptible variety MTU 1001, 18.90 per cent disease severity was recorded. Whereas, at 90 DAT the disease severity varied from 0.0 to 21.20 per cent.

Highest disease severity was recorded on variety Rathnachoodi (21.20\%) followed by variety CTH-3 which recorded 18.80 per cent disease severity. $0.0 \%$ disease severity was recorded on 11 varieties viz., Rasi, JGL-1798, BR-2655, Raksha, KMP-201, BI-33, Sag batta, Honnekattu, Klame, Kavekantak and Togarshi. However on susceptible variety MTU-1001, 19.50 per cent disease severity was recorded. Screening varieties against brown leaf spot disease has been under taken by several workers like Pannu et al., (2006), Yaqoob et al., (2011), Arshad et al., (2013) and Magar, (2015). Pannu et al., (2006) reported that disease severity varied from 0.15 to 28.41 per cent during 2000, 2001, 2002, and 2003 at Ludhiana and during 2000 and 2001 at Gurdaspur under artificial inoculation conditions. They further reported that from among 9 varieties screened, Jaya and PR 111 showed lower severity of 4.20 and 4.30 per cent, respectively. Similarly, Magar (2015) reported 21.73 to 58.07 per cent disease severity in 14 varieties screened during August-November, 2013. Since the B. oryzae is low sugar pathogen, as the nutrient status deplete in soil against age of the crop, pathogen invade and causes more damage, this might be the possible reason for increased disease severity at 60 and 90 days after transplanting.

Further, all the 50 paddy genotypes were further categorized into different groups based on the type of disease reaction and is as shown in Table 3. The symptoms expressed on these genotypes are shown in Plate 2. Eleven genotypes viz., Rasi, JGL-1798, BR-2655, Raksha, KMP-201, BI-33, Sagbatta, Honnekattu, Klame, Kavekantak and Togarshi showed immune reaction with $0.00 \%$ disease severity. Eight genotypes viz., Rajbhog, KMP153, Akkalu, MTU-1010, Sagvad, Bilidodibudda, Sannamullu and CTH-1 showed resistant reaction with 1-5 per cent disease severity. 31 genotypes viz., KMP-175, Tellahamsa, KMP 149-1, Thanu, Basumathi, Jeerigebatta, Puttabatta, Sannaki, Alurusanna, DRK Basumathi, Bilirajmudi, Mandyavijaya, IR-30864, MAS-26, KMP-128, Rajamudi, KMP 149-2, BPT-5204, Jyothi, IR-64, MAS946, Jaya, CTH-3, Ratbat, Theerthahalli selection, Manila, Doddaalur, MTU 1001, Tiruveni, KMP-200 and Rathnachoodi recorded moderately resistant reaction with disease severity of 6-15 per cent. 
Table.1 Standard evaluation system scale for brown leaf spot disease of paddy

\begin{tabular}{|c|l|}
\hline Score & Description \\
\hline 0 & No disease observed \\
\hline 1 & Less than $1 \%$ \\
\hline 2 & $1-3 \%$ \\
\hline 3 & $4-5 \%$ \\
\hline 4 & $6-10 \%$ \\
\hline 5 & $11-15 \%$ \\
\hline 6 & $16-25 \%$ \\
\hline 7 & $26-50 \%$ \\
\hline 8 & $51-75 \%$ \\
\hline 9 & $76-100 \%$ \\
\hline
\end{tabular}

Table.2 Screening of paddy varieties against brown leaf spot disease at Mandya during kharif 2015

\begin{tabular}{|c|c|c|c|c|}
\hline \multirow[t]{2}{*}{ Sl. No. } & \multirow[t]{2}{*}{ Varieties/Genotypes } & \multicolumn{3}{|c|}{ Disease severity (\%) } \\
\hline & & 30 DAT & 60 DAT & 90 DAT \\
\hline 1. & Rajamudi & 0.0 & 13.55 & 15.50 \\
\hline 2. & KMP-149-2 & 0.0 & 12.20 & 12.20 \\
\hline 3. & Rathnachoodi & 0.0 & 10.00 & 21.10 \\
\hline 4. & BPT-5204 & 0.0 & 07.70 & 14.40 \\
\hline 5. & KMP-175 & 0.0 & 07.70 & 07.70 \\
\hline 6. & MAS-26 & 0.0 & 06.60 & 06.60 \\
\hline 7. & Jyothi & 0.0 & 06.60 & 15.50 \\
\hline 8. & IR-64 & 0.0 & 10.00 & 13.30 \\
\hline 9. & Rasi & 0.0 & 00.00 & 00.00 \\
\hline 10. & Tellahamsa & 0.0 & 06.00 & 06.60 \\
\hline 11. & MAS-946 & 0.0 & 07.80 & 12.20 \\
\hline 12. & KMP-200 & 0.0 & 08.90 & 17.70 \\
\hline 13. & Jaya & 0.0 & 07.80 & 11.10 \\
\hline 14. & IR-30864 & 0.0 & 04.50 & 10.00 \\
\hline 15. & CTH-3 & 0.0 & 11.10 & 18.80 \\
\hline 16. & CTH-1 & 0.0 & 03.00 & 05.50 \\
\hline 17. & Mandyavijaya & 0.0 & 08.90 & 10.00 \\
\hline 18. & JGL-1798 & 0.0 & 00.00 & 00.00 \\
\hline 19. & MTU-1001 (check) & 0.0 & 10.00 & 18.50 \\
\hline 20. & BR-2655 & 0.0 & 00.00 & 00.00 \\
\hline 21. & KMP-153 & 0.0 & 03.00 & 03.30 \\
\hline 22. & Raksha & 0.0 & 00.00 & 00.00 \\
\hline 23. & KMP-201 & 0.0 & 00.00 & 00.00 \\
\hline 24. & MTU-1010 & 0.0 & 13.40 & 15.50 \\
\hline 25. & KMP-128 & 0.0 & 00.00 & 07.80 \\
\hline 26. & KMP149-1 & 0.0 & 03.50 & 04.30 \\
\hline
\end{tabular}

*DAT $=$ Days after transplanting 
Table.3 Disease reaction of paddy genotypes screened during kharif 2015 at Mandya

\begin{tabular}{|c|c|c|c|c|}
\hline Sl. No. & $\begin{array}{c}\text { Disease } \\
\text { severity }(\%)\end{array}$ & Disease reaction & $\begin{array}{l}\text { No. of } \\
\text { genotypes }\end{array}$ & Genotypes \\
\hline 1 & 0.0 & (0) Immune & 11 & $\begin{array}{l}\text { Rasi, JGL-1798, BR-2655, Raksha, } \\
\text { KMP-201, BI-33, Sagbatta, } \\
\text { Honnekattu, Klame, Kavekantak } \\
\text { and Togarshi. }\end{array}$ \\
\hline 2 & $1-5 \%$ & (1-3) Resistant & 8 & $\begin{array}{l}\text { Rajabhog, KMP-153, Akkalu } \\
\text { MTU-1010, Sagvad, Bilidodibudda, } \\
\text { Sannamullu. CTH-1 }\end{array}$ \\
\hline 3 & $6-25 \%$ & $\begin{array}{l}\text { (4-6) Moderately } \\
\text { resistant }\end{array}$ & 31 & $\begin{array}{l}\text { KMP-175, Tellahamsa, KMP 149- } \\
\text { 1, Thanu, Basumathi, Jeerigebatta, } \\
\text { Puttabatta, Sannaki, Alurusanna, } \\
\text { DRK Basumathi, Bilirajmudi, } \\
\text { Mandyavijaya, IR-30864, MAS-26, } \\
\text { KMP-128, Rajamudi, KMP 149-2, } \\
\text { BPT-5204, Jyothi, IR-64, MAS- } \\
\text { 946, Jaya, CTH-3, Ratbat, } \\
\text { Theerthahalli selection, Manila, } \\
\text { Doddaalur, } \\
\text { MTU } 1001 \text {, Tiruveni, } \\
\text { KMP-200 and RathnaChoodi }\end{array}$ \\
\hline 4 & $26-50 \%$ & (7) Susceptible & 0 & - \\
\hline 5 & $51-100 \%$ & $\begin{array}{l}\text { (8-9) Highly } \\
\text { susceptible }\end{array}$ & 0 & - \\
\hline
\end{tabular}

Similar results obtained by Alam et al., (2016) they 25 screened varieties against brown leaf spot caused by Helminthosporium oryzae during session Kharif2014 and 2015. The results were four varieties recorded viz. NDR$359, \mathrm{CR}-1, \mathrm{CR}-2$ and $\mathrm{N}-18$ in highly resistant. Seven varieties were recorded viz. PR-103, IR36, Prasd, Narendra-2, IR-597, OC-1339 and Cross-116 in resistant. Six varieties were recorded viz. IET-849, Pusa NR-381, Narendra80, Narendra Dhan-97, Jalnidhi and Jallahari in moderately resistant. Three varieties were recorded viz. Rupali, MTU-7029 and Sweta in moderately susceptible. IET-2969 and Annapurna was recorded in susceptible. Three varieties were recorded viz. Nagina-22, CR-126 and Cauvery highly susceptible in all three screening conditions, i.e. laboratory, pot and field.
In the present investigations, the varieties showing resistance against brown spot disease can be utilized as a source of resistance for breeding disease resistant lines of rice. Moreover, the late genotypes besides producing lower yields have also confusing behavior due to ambiguous response against diseases.

\section{References}

Agarwal, V. K., 1989, A simpler technique for routine examination of rice seed lots for rice brown leaf spot disease. Seed Technology News. Bulletin of the Indian Society of Seed Technology. 11:1-2.

Alam, S., Seth, R. K., Singh, H., Srivastava, J. N. and Shukla, D. N., 2016, Screening of Disease Resistant Varieties against Brown Leaf Spot of Oryza sativa in Allahabad, India. AJEA, 14(1): 1-11. 
Arshad, H. M. I., Hussain, N., Khan, J. A., Sallem, K. and Baber, M. M., 2013, Behavior of Bipolaris oryzae at different temperatures, culture media, fungicides and rice germplasm for resistance. Pakistan J. Phytopath., 25(1): 84-90.

Arshad, H. M. I., Khan, J. A. and Jamil, F. F., 2008, Screening of rice germplasm against blast and brown spot diseases. Pakistan J. Phytopathol., 20(1):52-57.

Bonman, J. M., Estrada, B. A., Kim, C. K., Ra, C. K. and Lee, E. J., 1991, Assessment of blast disease and yield losses in susceptible and partial resistant rice cultivars in two irrigated and low land environments. Pl. Dis., 75: 462-466.

Cardwell, K. F., Kling, J. G. and Bock, C., 1997, Methods for screening maize against downy mildew Peronosclerospora sorgi. Pl. Breeding, 116: 221-226.

Estrada, A. B., 1984, Selection of differential varieties for race study of Helminthosporium oryzae. M.S. Thesis. College, Leguna, the Philippines: University of Philippines at Las Banos, Philippines.

FAO Food Outlook Global Market Analysis, 2010, (Retrieved from November 2010) Available:

http://www.fao.org/docrep/013/al 969e/al969e00.pdf.

IRRI, 1996, Standard evaluation system for rice ( $4^{\text {th }}$ ed.). Manila, Philippine: IIRI.

IRRI, 2012, Rice facts. International Rice Research Institute, Manila, Philippines.

Khan, J. A., Jamil, F. F., Cheema, A. A. and Gill, M. A., 2001, Screening of rice germplasm against blast disease caused by Pyricularia oryza in: Proc. National
Conf. of Plant Pathology, held at NARC. Islamabad. pp. 6-9.

Magar, P. B., 2015, Screening of rice varieties against brown leaf spot disease at Jyotinagar, Chitwan, Nepal. Int. J. Appl. Sci. Biotechnol., 3(1): 56-60.

Mayee, C. D. and Datar, V. V., 1986, Phytopathpmety. Technical Bulletin-1 (special bulletin-3), Marathwada Agricultural University, Parbhani, Maharasthra, India, p. 29.

Mew, T. W., 1991, Disease management in rice. CRC Handbook of Pest Management. $2^{\text {nd }}$ Ed. Vol. III. D. Pimentel and A. A. Hanson, eds. CRC Press, Boca Raton. pp. 279-299.

Padmanabhan, S.Y., 1973, The great Bengal famine. Ann. Rev. Phytopathol., 11:11-26.

Pannu, P. P. S., Chahal, S. S., Vineeth, K. S., MandeepKaur, and Bagga, P. S., 2006, Occurrence of brown leaf spot of rice in Punjab, its effect on grain yield and its control. Indian Phytopath, 59(2): 190193.

Rangaswami, G. and Mahadevan, A., 1999, Diseases of crop plants in India. $\left(4^{\text {th }} \mathrm{Ed}\right.$.). Prentice Hall of India Pvt. Ltd., New Delhi.pp.165-169.

Webster, R. K. and Gunnell, P. S., 1992, Compendium of rice diseases. American Phytopathological Society, St. Paul, Minnesota. Pp. 62.

Yaqoob, M., Mann, R. A., Iqbal, S. M. and Anwar, M., 2011, Reaction of rice genotypes to brown spot disease pathogen Cochliobolus miyabeanu under drought conditions. Mycopath., 9(1): 9-11.

Zadoks, J. C., 2002, Fifty years of crop protection, 1950-2000. Netherland J. Agric. Sci., 181-193.

\section{How to cite this article:}

Channakeshava, C. and Pankaja, N.S. 2018. Performance of Paddy Varieties against Brown Leaf Spot Disease under Flooded Conditions in Mandya District, Karnataka, India. Int.J.Curr.Microbiol.App.Sci. 7(12): 33-38. doi: https://doi.org/10.20546/ijcmas.2018.712.004 